The lens is a unique biological structure, whose highly ordered molecular and cellular components are essential for transparency. Although disturbances in lens cell physiology are readily identified as opacification or cataract there is still much to learn about the normal structure and function of the lens and the mechanism of cataract formation. This issue of Eye contains papers from the 1998 Cambridge Symposium which brought together clinicians and basic scientists, from a broad range of disciplines, to discuss current research in lens development, physiology and the mechanism of cataract formation. This is a challenging and important field as cataract remains the most important cause of blindness world-wide.

Crystallin molecules are the major cytoplasmic proteins of the mature lens fibre. Thought originally to be present in the lens to provide transparency, they are in fact encoded by a family of genes that also specify metabolic enzymes and stress proteins found in other tissues. In their article, Horwitz and colleagues ${ }^{1}$ propose that even within the lens $\alpha$-crystallin has other important roles including chaperonelike activity. Another family of cytoplasmic molecules, the cytoskeletal proteins, present in the lens, are important in determining the structure of the lens cells and their ability to withstand physical stresses such as those occurring during accommodation. Current knowledge of the cytoskeletal proteins is reviewed by Quinlan et al. ${ }^{2}$ and Clark et al. ${ }^{3}$ provide evidence that they may also be critical for establishing and maintaining lens cell transparency.

McAvoy and co-workers ${ }^{4}$ in this issue summarise current opinion regarding lens development and highlight some of the future prospects for research in this area. An understanding of the developmental biology of the lens is particularly relevant to the study of congenital cataract. Although the aetiology of congenital cataract is diverse the most important cause is genetic mutation. Most genetic forms of cataract in man are inherited as an autosomal dominant trait although $\mathrm{X}$-linked and autosomal recessive forms do occur. The identification of genes which cause inherited cataract is the starting point for understanding the way in which abnormal development of the lens leads to opacification. Progress in identifying such genes has been aided by the wealth of candidate genes including those encoding growth factors, transcription factors and the lens crystallins and other structural proteins. ${ }^{5}$ Animal models have also been a useful resource. Over the past 30 years a large variety of mouse strains have been recognised with inherited lens opacities. In his extensive review of the subject Graw ${ }^{6}$ describes the diversity of these mouse cataract mutants and how they have helped us to understand normal lens physiology and the mechanisms that underlie cataract formation. The genetic mutations underlying some forms of mouse cataract have been identified and the lens phenotype is very similar to the human cataract associated with similar genetic mutations. ${ }^{5}$ To date mutations in seven different genes including those coding for components of the lens crystallins, lens cell gap junctions and transcription factors have been implicated in the development of inherited cataract in $\operatorname{man}^{7-13}$ and more remain to be discovered.

Human congenital cataract is rare but nonetheless the commonest treatable cause of childhood blindness. ${ }^{14}$ Although cataracts usually present as isolated ocular abnormalities, lens opacification is a recognised feature of almost 200 genetic disorders including galactosaemia, Lowe's syndrome and Down's syndrome. The review by Cassidy and Taylor ${ }^{15}$ concentrates on those syndromes where congenital cataracts are associated with dysmorphic features, categorising the information in a manner that is of great help to the ophthalmologist in the clinical setting. It remains a major challenge to identify the molecular genetic basis of these rare and complex disorders.

It is estimated that despite surgical removal of the lens and subsequent optical correction one-third of patients with bilateral congenital cataract will remain legally blind due to the presence of profound amblyopia. The outlook for the affected eye of a child with monocular congenital cataract is also poor, aphakia being as amblyogenic as the cataract itself. Lambert ${ }^{16}$ sets out the evidence from both clinical and animal studies that better visual acuity may be obtained by intraocular lens insertion following cataract removal during the sensitive period of visual development.

The prognosis for age-related cataract is much better; cataract extraction with intraocular lens insertion often returns vision to pre-morbid levels. However, posterior capsule opacification (PCO) occurs in up to $50 \%$ of patients causing significant post-operative morbidity.
P.J. Francis

Department of Molecular Genetics

Institute of Ophthalmology University College London London, UK

P.J. Francis

A.T. Moore

Moorfields Eye Hospital London, UK

\section{A.T. Moore}

Addenbrooke's Hospital Cambridge, UK

Anthony T. Moore, FRCS, FRCOphth Addenbrooke's Hospital Hills Road Cambridge CB2 2QQ, UK

Tel: +44 (0)1223216700 e-mail: atm22@hermes.cam.ac.uk 
Marcantonio and Vrensen ${ }^{17}$ in this issue review current knowledge of the cell biology of PCO and Spalton ${ }^{18}$ suggests that in the future the development of novel materials for intraocular lenses may reduce its incidence.

Although modern surgical techniques have improved the outcome after cataract surgery, most of the patients in the world who are blind from cataract do not have access to surgery. As Foster ${ }^{19}$ discusses in this issue it remains a major challenge to deliver cataract surgery to those most in need. The failure of health care systems to cope with the demand for cataract surgery also highlights the need for further research into the causes of cataract and possible methods of prevention.

\section{References}

1. Horwitz J, Bova MP, Ding LL, Haley DA, Stewart PL. Lens $\alpha$-crystallin: function and structure. Eye 1999;13:403-408.

2. Quinlan RA, Sandilands A, Procter JE, Prescott AR, Hutcheson AM, Dahm R, et al. The eye lens cytoskeleton. Eye 1999;13:409-416.

3. Clark JI, Matsushima H, David LL, Clark JM. Lens cytoskeleton and transparency: a model. Eye 1999;13:417-424.

4. McAvoy JW, Chamberlain CG, de Iongh RU, Hales AM, Lovicu FJ. Lens development. Eye 1999;13:425-437.

5. Francis P, Berry V, Moore AT, Bhattacharya S. Lens biology, development and human cataractogenesis. Trends Genet 1999;15:191-6.

6. Graw J. Mouse models of congenital cataract. Eye 1999;13:438-444.

7. Brackenhoff R, Heskens H, Rossum M, Lubsen N, Schoenmakers J. Activation of the gamma-E-crystallin pseudogene in the human hereditary Coppock-like cataract. Hum Mol Genet 1994;3:279-83.
8. Litt M, Carrero-Valenzuela R, LaMorticella D, Schultz D, Mitchell T, Kramer P, et al. Autosomal dominant congenital cataract is associated with a chain termination mutation in the human beta-crystallin gene CRYBB2. Hum Mol Genet 1997;6:665-8.

9. Semina E, Ferrell R, Mintz-Hittner H, Bitoun P, Alwar W, Reiter R, et al. A novel homeobox gene PITX3 is mutated in families with autosomal dominant cataracts and ASMD. Nature Genet 1998;19:167-70.

10. Litt M, Kramer P, LaMorticella D, Murphey W, Lovrien E, Weleber R. Autosomal dominant congenital cataract associated with a missense mutation in the human alpha crystallin gene CRYAA. Hum Mol Genet 1998;7:471-4.

11. Shiels A, Mackay D, Ionides A, Berry V, Moore A, Bhattacharya $\mathrm{S}$. A missense mutation in the human connexin 50 gene (GJA8) underlies autosomal dominant 'zonular pulverulent' cataract, on chromosome 1q. Am J Hum Genet $1998 ; 62: 526-32$.

12. Mackay D, Ionides A, Kibar Z, Rouleau G, Berry V, Moore A, et al. Connexin 46 mutations in autosomal dominant congenital cataract. Am J Hum Genet 1999;64:1357-64.

13. Stephan D, Gillanders E, Vanderveen D, Freas-Lutz D, Wistow G, Baxevanis A, et al. Progressive juvenile-onset punctate cataract characterised by mutation of the gamma-Dcrystallin gene. Proc Natl Acad Sci USA 1999;96:1008-12.

14. Lambert S, Drack A. Infantile cataracts. Surv Ophthalmol 1996;40:427-58.

15. Cassidy L, Taylor D. Congenital cataract and multisystem disorders. Eye 1999;13:464-473.

16. Lambert SR. Management of monocular congenital cataracts. Eye 1999;13:474-479.

17. Marcantonio JM, Vrensen GFJM. Cell biology of posterior capsular opacification. Eye 1999;13:484-488.

18. Spalton DJ. Posterior capsular opacification after cataract surgery. Eye 1999;13:489-492.

19. Foster A. Cataract - a global perspective: output, outcome and outlay. Eye 1999;13:449-453. 